\title{
PERCEPTUAL AND COMMUNICATION CRISIS IN AGRICULTURAL CONSTRUCTION PROJECT
}

\author{
Michal Vondruska \\ Czech Technical University in Prague, Czech Republic \\ michal.vondruska@fsv.cvut.cz
}

\begin{abstract}
Some projects are characterized by excessive risk accumulation. We are able to identify and eliminate these risks to a certain extent according to a number of applied standard risk management procedures. However, only few economic subjects are able to react effectively and efficiently when risks are activated. We call this event a project crisis and a consequent effort to lead the project back to normal crisis management. Finding the principles of crisis management is a difficult process, as neither project management nor crisis management are exact disciplines. Therefore, we must start from the essence of the best practice method - by generalizing the best experience. But who wants to share that his management system has failed and his project is in crisis? Thus, we are left with collecting all knowledge available and often in reverse way - by analyzing the worst practise - we compile possible crisis management schemes. By their nature, construction projects are prone to crisis situations. Construction preparation must take into account a wide range of risks. In addition to the technical aspects of the construction, there are also hardly definable aspects from the perception of the project in its ecological intentions. Poorly chosen communication principles and poor presentation of environmental characteristics to the public can bring the planned project into serious crisis already in its initial phase. This article deals with possible ways of crisis management and crisis communication in case of perceptual and communication crisis and uses the pig farm modernization project in Těšňovice near city of Kroměřiž as a case study.
\end{abstract}

Keywords: crisis, communication, perceptual.

\section{Introduction}

We consider the project crisis to be an unstable situation where the balance of the basic characteristics of the project is disturbed. This situation poses a serious threat to the project's priority objectives. Project management comes under high pressure and tensions arise between the participants of the project. The crisis arises as a result of a combination of internal weaknesses of the project and external threats. This means applying specific project risks. If the project management responds to active risks late or insufficiently, a crisis situation arises. In this state, project management is burdened with a high level of uncertainty for the next procedure. At the same time, project management must choose between hard-to-evaluate or hard-to-identify options.

\section{Literature review}

Construction projects are particularly susceptible to crisis situations due to the large number of project participants, long-term preparation, various legislative conditions, environmental conditions, financial entitlements, etc. [1;2] According to M. Loosemore [3], the crises in construction projects in American research were sorted by frequency in descending order as: delays in construction, design errors, cost overruns, mismanagement, activities of activists and interest groups against the implementation of the project, appeals and complaints in a public tender, legal disputes, mergers or acquisitions of the owner or contractor, and accidents during construction. Taking into account the current progress of the COVID 19 world pandemic, it is appropriate to mention in this overview the general distribution of crises in terms of the object of impact or origin. From this point of view, crises can be divided into crises: personal, social crises, crises due to natural disasters and accidents, economic crises. With the probability of bordering on certainty, all pandemic consequences will be reflected in this division and in construction projects.

A number of theories are being addressed in the ways of crisis management. However, the shift to building practice is very gradual. Based on its own $[1,4]$ survey, it was found that most construction companies are hiding their experience of the crisis situation and are not sufficiently prepared for it. Project manuals of even the largest construction companies are mostly engaged only in risk management, but no longer crisis management. That is, situations where risks are activated. However, construction firms agree that even a crisis in a small project can cause the loss of the Company's Good Will and cause existential difficulties. Crisis management itself can be divided into the management of a situation where a crisis has already occurred - subsequent crisis management and a situation in which 
we are trying to predict and manage the crisis proactively - proactive crisis management. Some theories speak of the dynamics of the crisis [3] and the need to repeat the crisis management cycle. Based on practical knowledge of the interconnection of corporate and project management, the dynamic management cycle has been slightly modified into the logical process of crisis management (Fig. 1). The interaction of company and project structures guarantees consistency of the crisis management process. This method has already been successfully applied in the crisis management of several projects and its principle subsequently adapted by construction companies into the extension of the project manual.

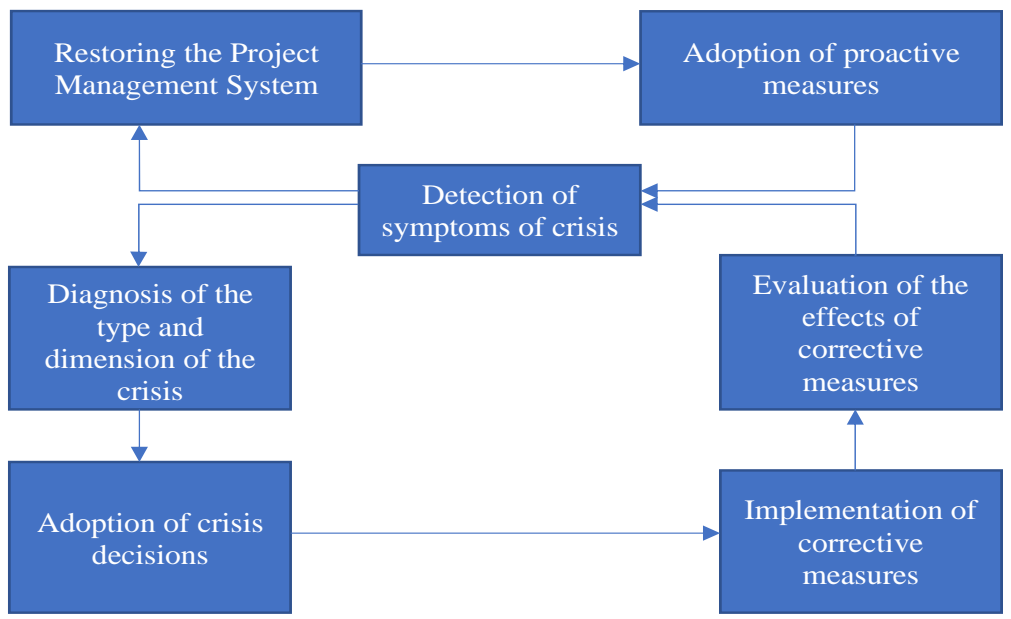

Fig. 1. Logical process of crisis management

Construction projects are specific in their uniqueness. Each construction project, even though it is the same building (e.g., supermarket), is created in a different place, in a different period, with other suppliers, etc. Based on its experience and functioning management system, the construction company can relatively well identify and manage risks. However, all risks cannot be consistently predicted and avoided. What appears to be a slight risk in one project may trigger a serious crisis on a similar project. Therefore, in construction it is very difficult to determine the symptoms of the emerging crisis. Success is therefore based on the creation of an early warning system to detect the symptoms of a crisis. The essence of this system is the monitoring of negative trends in the project. According to pre-prepared procedures, you are looking for answers to questions whether: Does the resulting trend in project dynamics correspond? Does the trend have a positive or negative effect on the project? Is the trend cyclical? Is the trend the result of another trend? Are there links between trends? The structure of the early warning system should be based on the requirement to identify the symptoms of the internal environment of the project and its surroundings in the matrix (Table 1).

Table 1

Matrix for early warning system

\begin{tabular}{|c|c|c|}
\hline Symptoms of the crisis & Quantifiable & Non-quantifiable \\
\hline Occurrence within the project & A & B \\
\hline Occurrence outside the project & C & D \\
\hline
\end{tabular}

The matrix consists of four segments. Segment A includes quantifiable data that arise within the project. The data are examined from the point of view of the past and are very well available. In construction projects it is an economic evaluation of the project on the basis of financial (better managerial) accounting, evaluation of the time schedule, quality records, safety monitoring, etc. Segment B includes non-quantifiable project data. These are soft, rather weaker signals, which are related to interpersonal problems in the construction project, e.g., relationship owner of the projectoffices, owner of project-architects, project manager - architect, etc. For these types of signals, checklists can be created and monitored. $\mathrm{CaD}$ segments are focused on external influences that affect project goals. Not only the managers of a particular project, but also stakeholders, can come to discover these factors. These include interest groups, such as investors, banks, government bodies, activists, etc. 
Crisis communication is an important tool for crisis management. The planning of crisis communication in construction projects is part of the process of proactive crisis management. Crisis communication planning prepares the system for its own internal responses and responses that the system will face after the outbreak of the crisis. The basic questions that the crisis management of a construction project must answer are: Is there a reason for crisis communication? Who to inform and in what order? Who will provide the information? When to implement the communication? How to communicate information?

\section{Materials and methods}

The methods used are based on the main best practices based on case study. The data in the case study are collected from the author's research. Possible procedures for general risk management and steps in issues of crisis management are mentioned by the authors [3],[5],[6]. Since this work is a practical management issue, a decision algorithm has been compiled in Fig. 2.

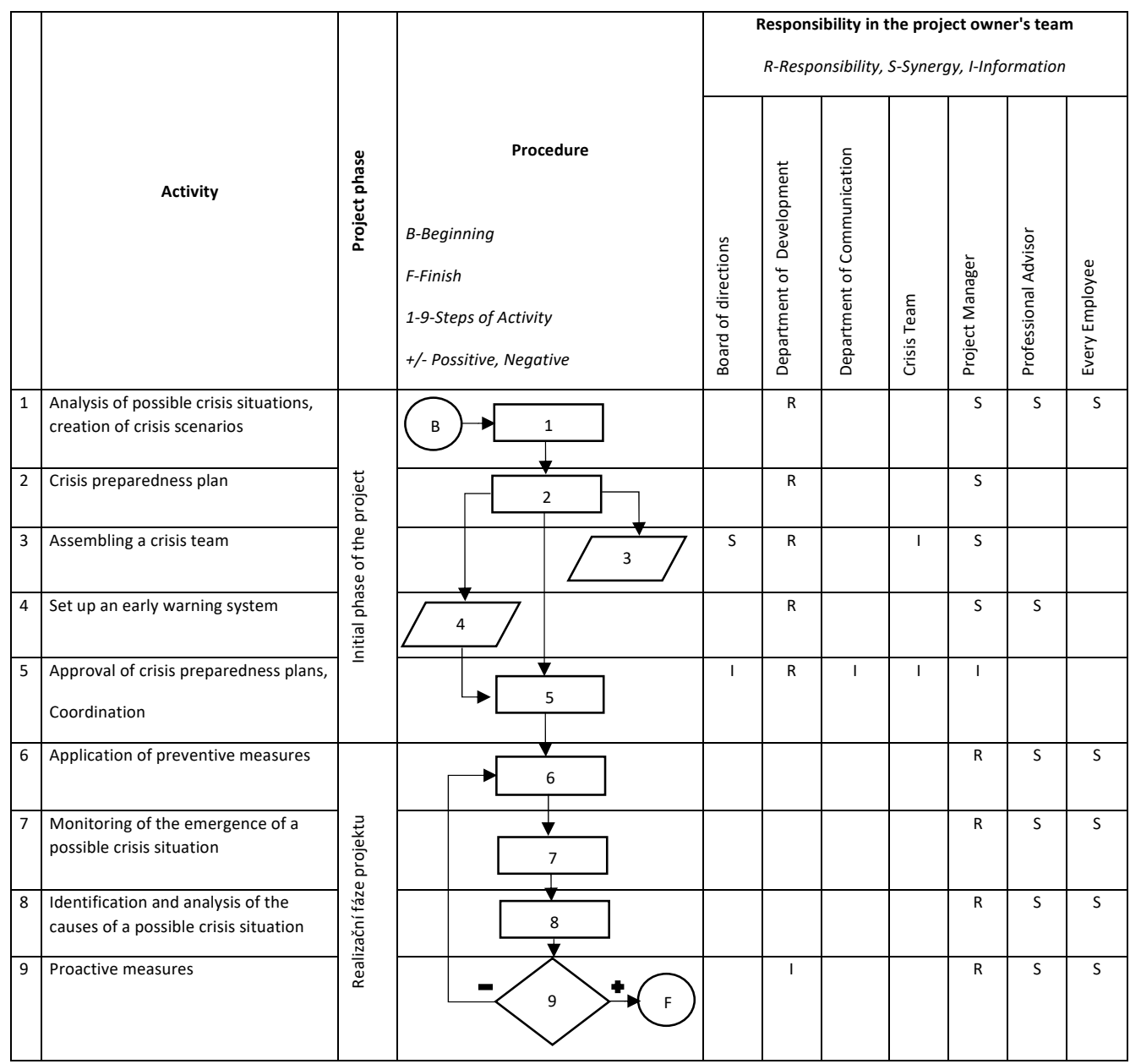

Fig. 2. Steps in issues crisis management (by the author)

\section{Case study: crisis communication in case of perceptual and communication crisis of the pig farm modernization project in Těšňovice near city of Kroměř̌̌̆.}

SZP Těšnovice a.s. is a specialized company for the production of pork. The average animal status on the Těšnovice farm is 22000 pigs, of which 1550 sows of the basic herd are raised, from which approximately 54000 piglets per year are raised. Total meat production is 4100 tonnes per year. In accordance with its strategy of increasing production and streamlining production, the company has prepared a project to modernize the existing equipment (Fig. 3). The basic objectives of the project are to increase the existing breeding and the related modernization of the premises. The project time schedule was including legislative and project preparation of construction from 2015-2019. 
Construction costs will be covered partly with own resources and partly from support funds, which build on the planned timetable.

The SZP company submitted to the regional environmental authorities a planned change in the use and operation of the plant entitled "Intensive pig meat breeding plant and intensive sow facility", which consists in increasing the capacity of the plant. The increase in the capacity of the plant was divided into two stages, of which in the first stage the operator plans to increase the number of pigs for slaughter by 3816 in the period of agemaking and in II. The fattening section increased by 5284 piglets, pre-fattening by 2520 piglets and increased the number of sows born and lactating by $20 \mathrm{pc}$. As part of the announced change, the operator also plans to install reducing technologies - biological air washing machines, odour filters for two slurry pits and stables, where the installation of a biological air washing machine is not planned for use of feeding stuffs containing enzyme preparations with a higher efficiency rate from $30 \%$ to $40 \%$. It can be seen from the published brief summary that there will be an overall increase in the capacity of the animals kept, especially in the fattening sector, when in the first stage there will be an increase from the current 9140 pieces to the planned 12956 pieces. The SZP has presented the concept of changes to the equipment, of which the essential ones consist in the demolition of 4 pcs. existing halls with the construction of a 1-new hall at this site with a capacity of 7296 carcasses (the original capacity in the old halls was 3480 ).

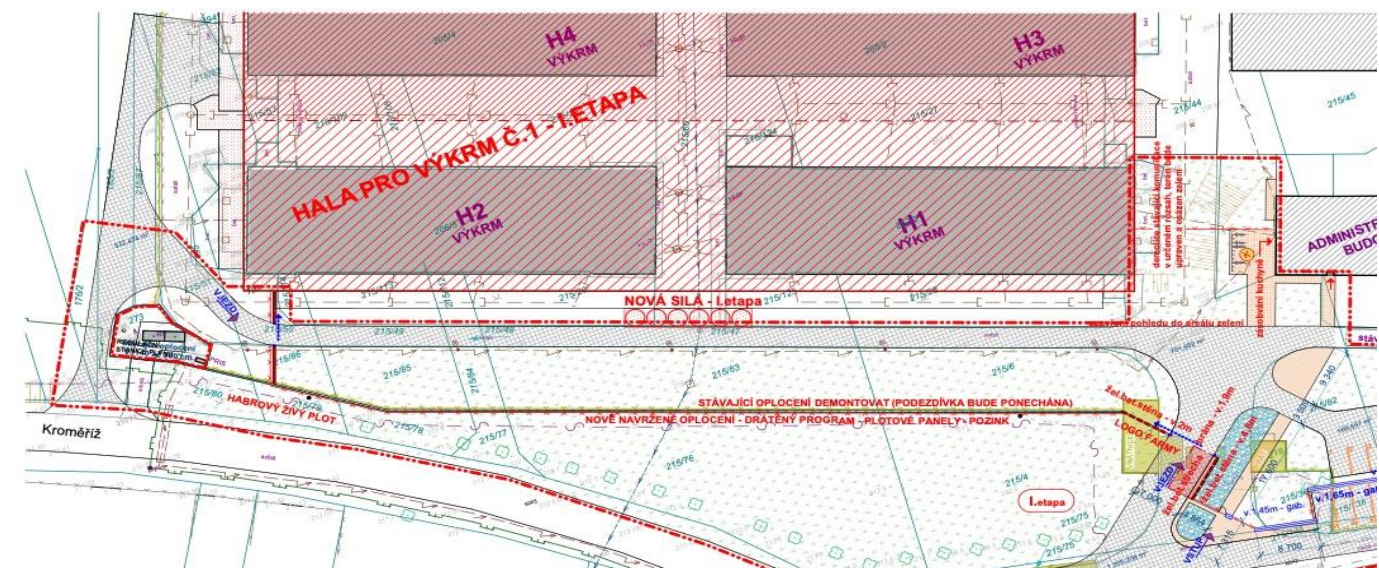

Fig. 3. Situation drawing of pig farm modernization (by the author)

\section{Analysis of the issue - identifying the bizarre and perceptual crisis of the project in its initial phase}

A biological washing machine with minimal efficiency will be installed on the new stable to reduce ammonia and odour emissions by $70 \%$. At the same time, the odour filter is installed on two slurry sumps. For other stables, where a biological air washing machine will not be used, enzymatic preparations with a higher efficiency of up to $40 \%$ will be used. The operator plans, before the start of II, to submit a new plan to authorised measurement of the installed biological washing machine and the determination of its real efficiency under the given conditions. In II 4 other halls will be demolished on the stage, with 2 new halls with a capacity of 7296 carcasses (the original capacity in the old halls was 3 050). As in Stage I, a biological washing machine with a minimum efficiency of reducing ammonia and odour emissions by $70 \%$ will be attached to the second stable. Furthermore, 2 more halls will be demolished, with hall No. 3 with a capacity of 3648 slaughter pigs being built in their place (the original capacity of the old halls was 1,740). Also here, a biological washing machine with the same required efficiency will be connected to this stable to reduce ammonia and odour emissions. Hall No. 6 will serve for pre-fattening piglets instead of the current fattening, with an increase from the original capacity of 870 piglets to the final number of 2520 piglets. The $\mathrm{P} 1$ stable for sows will undergo a refurbishment and the appropriate choice of layout will increase the capacity from 160 sows to 180 pieces. According to the operator's conclusions, the total capacity of the plant should be 18240 pig carcasses, sows giving birth and breastfeeding 732, juniper and pregnant sows 1 980, 12730 pre-fattening, 1200 piggies, a quarantine stable of 470 and boars of 20 pieces. With modernisation and increase of the equipment capacity, other indicators such as the consumption of raw materials, feed, water, excipients, energy, as well as the production of emissions, waste, slurry, wastewater, etc. will be increased. In the case of biological washing machine technology, the first stage will be tested in the plant under the conditions 
of the installation and authorised measurement of the emissions of ammonia and odour at the inlet and outlet of the biological washing machine in order to objectively assess the effectiveness of this technology and could then be installed on other newly built stables.

This is followed by the consent of the state authorities to the construction.

The first-level authority has gathered all the necessary supporting documents for the decision to amend the Integrated Authorisation, including the observations of the parties and the decision on the modification of the conditions of operation of the establishment under the heading 'Intensive pig-rearing establishments and intensive sows', on 21 December 2005, 11. 2017 gave its consent to the implementation.

This is followed by the appeal of the activists.

Note: However, the parties to the procedures for issuing an integrated permit are always civil associations (associations), companies in general, employers' associations or chambers of commerce, whose activities are the promotion and protection of professional interests; (according to $\S 8 \S 7(1)(e)$ of the Integrated Prevention Act [7].

Party - activist "Hortus Moravia" filed a complaint on 12 December 2017 appeal against this decision. The appellant notes in the appeal that the facility is already an important source of odour complaints, which cause respiratory problems and allergies to residents of surrounding properties, mainly caused by ammonia. Psychosomatic problems occurring in these people are caused by the constant presence of a smell, which makes it impossible for property dwellers to ventilate, and to carry out normal daily normal activities. It also refers to the impairment of properties located around the facility, manifested by a decrease in their prices. The area has not deteriorated significantly and notes that even a $30 \%$ increase in emissions of odour, ammonia, dust, bacteria from biological washing machines from each hall is trite. It is argued that, in order to prevent pollutant emissions by providing technical safety measures to reduce emissions, it is not enough to describe the installation, but it is necessary to assess whether those measures and technologies are capable of achieving guaranteed values. The appellant also draws attention to the fact that the mere description of the equipment is completely inadequate, lay and erroneous. Such a description of the technology to eliminate odour and stable gas emissions does not, in the opinion of the appellant, give confidence in the guaranteed efficiency of the technology in question. In support of his opinion, the appellant refers to the conclusions of the expert assessment of the technology by a specialist from the University of Chemical Technology in Prague. At the same time, the appellant called the previous EIA process illegal.

This is followed by a rejection of the appeal.

After examining the contested decision, the appeal body (Ministry of the Environment) did not find the appeal to be justified and upheld the contested decision on the grounds that the purpose of the law is, in accordance with the European Union law, to achieve a high level of environmental protection as a whole by applying integrated pollution prevention and control resulting from the activities listed in Annex 1 to that law [7] using the best available techniques and technologies.

A new appeal follows.

In 2018, activists also appealed against this decision by the Ministry of the Environment. The matter has not yet been decided. By continuing the preparatory work, the project owner is at considerable risk of thwarting investments and the project is temporarily suspended.

\section{Identification of the communication crisis of the project}

All of the above steps have been discussed in a public forum and through the media. The positions of the opposing parties and the main arguments in the discussions are summarised in the following table (Table 2).

\section{Conclusions of the analysis}

It is clear from the analysis of the issue that the project is in a state of bizarre and perceptual crisis in its forcibly ending depth. How it will be addressed will be shown by the future and ability of the project management. If the activists' appeal is rejected, the project and standard management mechanisms will be restarted. However, let us look at how crisis communication could have been conducted, which could have mitigated the consequences or prevented the current situation. Here we 
know that it is necessary to look for compromises. If one of the parties asserts their intention in a forceful manner, they can expect a strong counter-strike in the future.

\section{Possibilities of crisis communication solutions in a case study}

Crisis communication is an important tool for proactive crisis management and is closely related to risk management. Especially in construction projects, where project risk analysis reveals a large number of potential dangers of perceptual to bizarre character. This case is also a case study. The planning of crisis communication must then take place in the earliest stages of the project. It often happens that the prematurely voiced idea of the project can provoke rumours and negative acceptance of the intention in future participants, incl. public. Crisis communication planning prepares the system for its own responses. The results of the process must be regularly revised and updated. The starting point is the answers to elementary questions. Is there a reason for the crisis documentation? Who to inform and in what order? Who will provide the information? How to communicate information?

Table 2

\section{Main arguments in discussions of the opposing parties}

\begin{tabular}{|c|c|}
\hline View of activists & Project owner view \\
\hline $\begin{array}{l}\text { The existing equipment overburdens the smell of } \\
\text { the village and its surroundings. } \\
\text { Capacity expansion will increase odour and traffic } \\
\text { load. } \\
\text { The premises in any form depreciate real estate } \\
\text { prices. } \\
\text { We have a distrust of the proposed technology, the } \\
\text { effects of which cannot be verified in advance or } \\
\text { after. } \\
\text { You cannot transfer responsibility for future odour } \\
\text { to the manufacturer (dealer) of the technology. }\end{array}$ & $\begin{array}{l}\text { - We can operate the current situation without } \\
\text { improving the technology. } \\
\text { We have the right to realize an intention on } \\
\text { our own land that improves the economy of } \\
\text { operation and at the same time contributes to } \\
\text { the improvement of the environment. } \\
\text { The source of the odour is not just from us, it } \\
\text { is not measurable. We do business in the } \\
\text { agricultural field. }\end{array}$ \\
\hline Resulting attitude of activists & Resulting position of the project owner \\
\hline $\begin{array}{l}\text { We will take advantage of all shortcomings in the } \\
\text { area of legislative authorization of the building and } \\
\text { we will constantly appeal and hinder the } \\
\text { development of the premises. }\end{array}$ & $\begin{array}{l}\text { - If we fail to enforce our plan, we will not } \\
\text { modernize anything on the premises that will } \\
\text { contribute to improving the status quo. }\end{array}$ \\
\hline
\end{tabular}

\section{Choice of principles of crisis communication for a case study}

Compliance with the general principles of its management is essential for crisis communication. There are a number of principles of crisis communication for different types of crises. In our case study, based on the available information from the previous analysis, we could use these principles.

Principle of independence - all information submitted to project participants and public must be verified from several independent sources. In our example, this applies in particular to the efficiency of air washing machines.

The principle of public relations - it is advisable for the owner to build a positive perception of his business before starting the planned project. It is recommended, for example, to sponsorship of social and sports events, organized excursions and the like.

The principle of honesty, objectivity and openness. All information that is provided must be true, although the truth may not be revealed in its entirety. If any shortcomings in the planned project are revealed, it is necessary to accept them with humility and openly and work objectively on the modification of the project.

The principle of continuous satisfaction of trusted media. The project owner must have trusted media on his side. Obviously, at the moment, when there is a hunger for stunts, this is a difficult and long-term task. The media must be informed of the intention in advance and with some exclusivity. In our case, unfortunately, the owner focused only on presenting the project through his own website and public discussion of the project, which is part of the construction procedure. This was mostly attended only by opponents of the project and the press, who informed the previously unknown public about the negative attitudes of the activists. 
The principle of empathy. Public discussion is always emotional. The natural characteristic of a person is the fear of the unknown and the fear of repeating negative experiences. The owner must act as an empathetic personality, who is accustomed to communicating in tense situations, understands psychology. In our case, the discussion resulted in a statement that "If we do not promote the project, we will not modernise anything in order to improve the status quo".

The principle of searching for support. From the experience of other [4] projects, it seems very effective to create a very effective (even very small) group of the public supporting the project. In our case, it could be employees of the company, who will improve the working conditions, increase employment, etc. Another group may be members of a supported sports club, partner farms that take slurry, etc.

\section{Results and discussion}

When planning crisis communication in an investment project, it is necessary to define the position of the project within the organizational structure of the company and its communication flows and the competence of the project manager. According to best practice, the planning of crisis communication consists in setting the objectives and tasks of crisis communication, analysing risks and comparing possible crises, shaping the basic topics of crisis communication and developing a crisis communication plan. Compliance with the above selected principles of crisis communication is automatically assumed.

The results of the analysis of crisis communication and the proposal of a suitable crisis management procedure are clearly arranged in Table 3 .

\section{Analysis of crisis communication}

Table 3

\section{Communication before crisis}

\begin{tabular}{|c|c|}
\hline $\begin{array}{l}\text { Allocation of competences } \\
\text { for crisis communication }\end{array}$ & $\begin{array}{l}\text { Perform role splitting in project control. (This was not actually done. The farm's } \\
\text { executive director acted as a technical expert, project manager and press officer) }\end{array}$ \\
\hline $\begin{array}{l}\text { Setting criteria for crisis } \\
\text { recognition }\end{array}$ & $\begin{array}{l}\text { Set up an early warning system. (Hard and soft signals in the form of negative } \\
\text { perception of the farm and protests were evident already in previous projects) }\end{array}$ \\
\hline $\begin{array}{l}\text { Create rules of conduct in a } \\
\text { crisis }\end{array}$ & $\begin{array}{l}\text { Compile a manual of corporate communication. (A clear guide and its reduced } \\
\text { outputs for the counterparty improve the orientation of both sides. The main } \\
\text { benefit, however, is the separation of the issue of construction from the delicate } \\
\text { balance of perception of the farm itself and the rest of the holding) }\end{array}$ \\
\hline \multicolumn{2}{|r|}{ Communication in crisis } \\
\hline $\begin{array}{l}\text { Analysis of symptoms of } \\
\text { the crisis }\end{array}$ & $\begin{array}{l}\text { Evaluation of the outputs of the early warning system. (It is mainly evaluated } \\
\text { what the effects of the emerging crisis have on project objectives. In our case, it } \\
\text { relates, for example, to whether the delay in the project will affect the acquisition } \\
\text { of time-limited financial support and deepening of the negative perception of } \\
\text { traffic) }\end{array}$ \\
\hline $\begin{array}{l}\text { Definition of the target } \\
\text { group of recipients of } \\
\text { information, } \\
\text { communication lines and } \\
\text { forms of communication }\end{array}$ & $\begin{array}{l}\text { Activation of the communication manual. (For each area of the issue, appoint a } \\
\text { spokesperson. The division of roles dilutes targeted and often misleading attacks } \\
\text { by activists. It is important that section-only speakers stick to their topics) }\end{array}$ \\
\hline $\begin{array}{l}\text { Monitoring and updating of } \\
\text { crisis communication }\end{array}$ & $\begin{array}{l}\text { Modification of the manual. (Crisis is dynamic and constantly evolving. It can be } \\
\text { assumed that the counterparty also has a communication plan. The rules that are } \\
\text { set at the beginning may not be effective throughout the development of the } \\
\text { situation) }\end{array}$ \\
\hline \multicolumn{2}{|r|}{ Post-crisis communication } \\
\hline $\begin{array}{l}\text { Detailed analysis of the } \\
\text { crisis and the effects of } \\
\text { crisis communication }\end{array}$ & $\begin{array}{l}\text { Detailed analysis of the crisis situation and communication in crisis. (This } \\
\text { analysis will help improve the early warning system and the communication } \\
\text { strategy of the entire holding) }\end{array}$ \\
\hline $\begin{array}{l}\text { Formulation of tasks for } \\
\text { communication in the post- } \\
\text { crisis period }\end{array}$ & $\begin{array}{l}\text { Modification of the manual (Even in the post-crisis period, the increased interest } \\
\text { of the counterparty and the media in the project can be assumed. The opposing } \\
\text { party is waiting for your mistakes. Positive communication with the media can } \\
\text { improve the overall perception of the operation of the farm and holding in the } \\
\text { next stages of the project or of other projects) }\end{array}$ \\
\hline
\end{tabular}


The crisis management procedure in the situation of perceptual crisis of the project can be adjusted to the algorithm in Fig. 4.

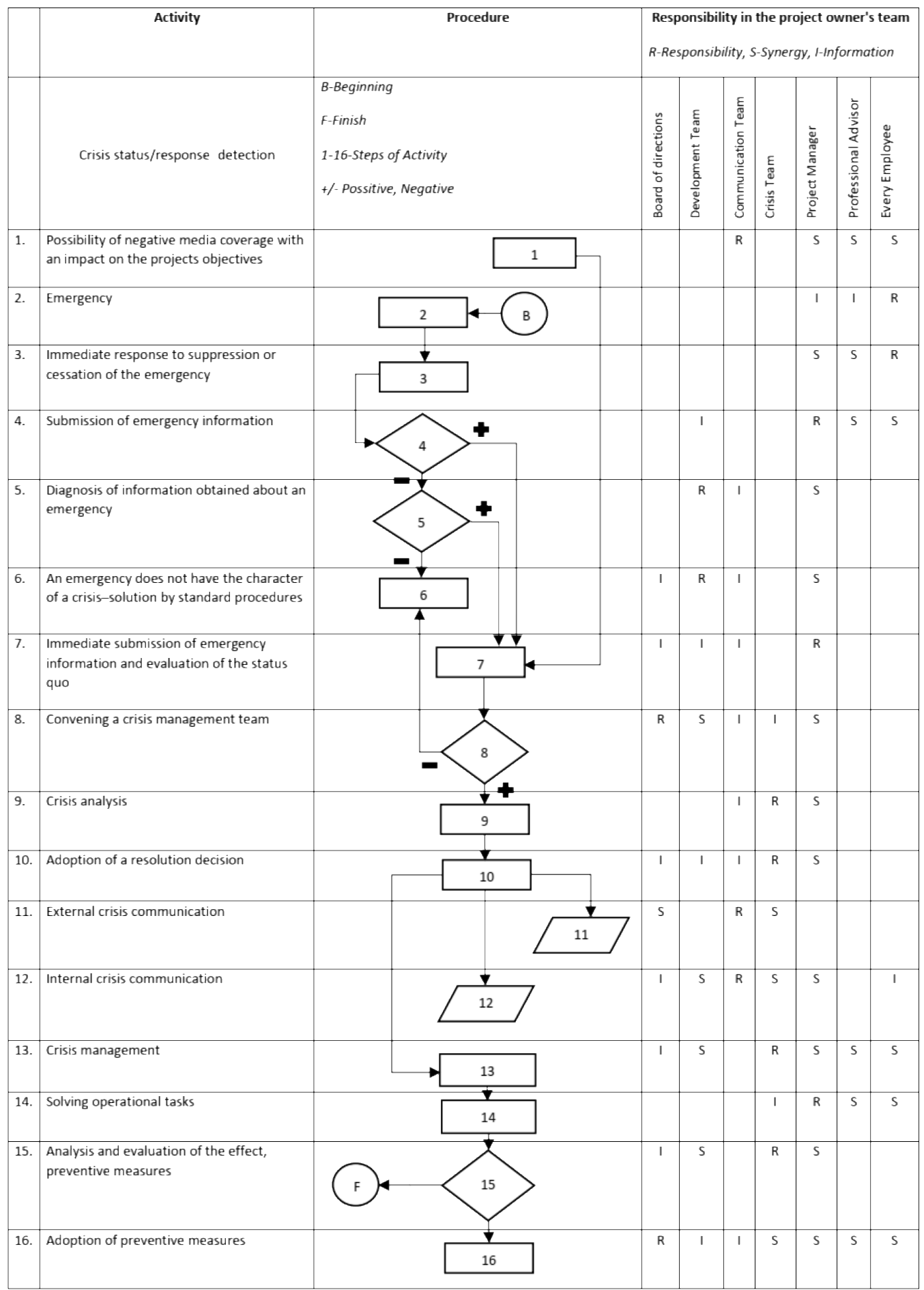

Fig. 4. Steps in issues crisis management of perceptual crisis (by the author)

\section{Conclusions}

At present, the management of construction projects is often exposed to the possibility of negative medialization of the construction project, which can have a major impact on the objectives of the project. In the event of such an emergency - a perceptual crisis, it is necessary to react quickly to suppress or stop the emergency. Project management should have prepared an early warning system and methodological aids for evaluating the information obtained about the emergency. If the situation cannot be resolved by standard project management procedures, the project owner must be informed 
immediately and the formation of a crisis team must be initiated. Decisions on how to deal with the crisis are taken on the basis of crisis scenarios and expert analysis. Perceptual crises are of a communication nature, so it is necessary to strictly follow the principles of crisis communication. The tool for successfully managing a crisis situation is perfectly managed external and internal crisis communication, which must be supported by a consistent solution of operational tasks.

Crisis communication procedures in crisis scenarios are divided into pre-crisis communication design, crisis communication and post-crisis communication. Pre-crisis communication consists of allocation of competences for crisis communication, setting criteria for crisis recognition and create rules of conduct in a crisis. Communication in crisis involves an analysis of the symptoms of the crisis, definition of the target group of recipients of information, communication lines and forms of communication and monitoring, and updating of crisis communication.

It is proposed to follow a dynamic crisis management cycle until all symptoms of the crisis have been completely removed. After successfully managing crisis management, project management is returned to normal. However, the crisis management procedures carried out are analysed in great detail and make a proposal for new preventive measures and an early warning system. An important aspect is also post-crisis communication, which consists in detailed analysis of the effects of crisis communication and formulation of tasks for communication in the post-crisis period.

\section{References}

[1] Vondruška M. Krizové ř́zení stavebních projektů: Crisis management in the construction projects. Brno: Akademické nakladatelství CERM, 2013. ISBN 978-80-7204-847-2

[2] Antušak E., Kopecky Z. Úvod do teorie krizového managementu I. 2. vyd. V Praze: Oeconomica, 2003. ISBN 80-245-0548-7.

[3] Loosemore M. Crisis management in construction projects. Reston, Va.: American Society of Civil Engineers, c2000. ISBN 978-0784404911.

[4] Tomek A., Vondruška M., Tomek R. Metodology for preparation of transport infractructure constructions in Design-Build delivery system. Prague: Fakulta stavební, ČVUT, Centrum pro efektivní a udržitelnou dopravní infrastrukturu (CESTI), 2019. ISBN 978-80-01-06664-5.

[5] BALOG, Michal a Angelina IAKOVETS. Risk management: theory, background, practice. Prague: Leges, 2020. Teoretik. ISBN 978-80-7502-463-3.

[6] Diers-Lawson, (2017-09-26) Crisis Communication. Oxford Research Encyclopedia of Intergroup Communication. [online] [21.03.2021] Available at: http://communication.oxfordre.com/view/10.1093/acrefore/9780190228613.001.0001/acrefore9780190228613-e-397.

[7] Zákon o integrované prevenci 76/2002 sb. The Integrated Prevention Act, Czech Ministry of the Environment. 